\title{
ASPEK PSIKOSOSIAL PADA PENDERITA KANKER PAYUDARA: STUDI PENDAHULUAN
}

\author{
Siwi Setya Utami, Mustikasari* \\ Fakultas Ilmu Keperawatan Universitas Indonesia, Depok 16424, Indonesia \\ *E-mail: mustikasari@ui.ac.id
}

\begin{abstract}
Abstrak
Kanker payudara sebagai jenis kanker yang paling banyak diderita perempuan Indonesia, dipandang dapat mengganggu aktivitas sehari-hari, mengubah penampilan fisik, sulit disembuhkan, serta dekat dengan kematian, sehingga berdampak pada aspek psikologis penderita. Studi potong lintang ini bertujuan untuk mengidentifikasi hubungan anatara karakteristik penderita kanker payudara dengan aspek psikososial. Sebanyak 44 responden dilibatkan. Pengukuran aspek psikososial menggunakan Depression, Anxiety, and Stress Scale (DASS) versi Bahasa Indonesia. Hasil penelitian menunjukkan masalah psikososial yang paling banyak dialami responden berdasarkan tingkat keparahannya yaitu ansietas $(9,1 \%)$. Karakteristik responden dan karakter kanker payudara tidak berhubungan dengan depresi, ansietas, dan stres, namun ditemukan adanya hubungan antara pendidikan dengan ansietas $(\mathrm{p}=0,041)$. Penelitian lanjutan perlu dilakukan untuk mengidentifikasi masalah psikososial lainnya dan tindakan keperawatan yang diperlukan oleh penderita kanker payudara untuk mengatasi masalah tersebut. Ansietas perlu difokuskan sebagai masalah psikososial yang paling menonjol pada penderita kanker payudara.
\end{abstract}

Kata kunci: ansietas, aspek psikososial, depresi, kanker payudara, stres

\begin{abstract}
Psychosocial Aspects of Breast Cancer Patients: Pilot Study. Breast cancer is the most common type of cancer suffered by Indonesian women, which is seen to disturb the daily activities, changing the physical image, difficult to cure, and close to death, thus affecting the psychological aspects of the patient. This cross-sectional study aimed to identify the relationship between characteristics of breast cancer patients with psychosocial aspects. A total of 44 respondents were involved.Psychosocial aspects were measured using the Indonesian version of the Depression, Anxiety, and Stress Scale (DASS). The results showed that psychosocial problems that the most experienced by respondents based on the severity was anxiety (9.1\%), characteristic of the respondents and breast cancer characteristic was not related to depression, anxiety, and stress., however, there was association between respondent's education and anxiety $(p=0.041)$. Further research needs to be undertaken to identify other psychosocial problems and nursing interventions needed by breast cancer patients to address the problems. Anxiety needs to be focused on the most prominent psychosocial problem in breast cancer patients.
\end{abstract}

Keywords: anxiety, breast cancer, depression, psychosocial aspects, stress

\section{Pendahuluan}

Kanker adalah penyakit sel yang dikarakteristikan dengan proliferasi sel yang tidak terkontrol (Sarafino \& Smith, 2012). Kanker juga seringkali disebut tumor ganas. Masyarakat di banyak bangsa seringkali menganggap kanker merupakan penyakit yang tidak bisa disembuhkan, penyakit pengantar kematian, dan lebih sering dialami oleh orang yang sudah berusia lanjut (Remennick, 2006).

Angka kejadian kanker di dunia sangat tinggi dan terus meningkat. Menurut data World Health Organization (WHO) tahun 2013, insiden kanker di dunia meningkat dari 12,7 juta kasus pada tahun 2008 menjadi 14,1 juta kasus tahun 2012. Tidak hanya itu, angka kematian akibat kanker 
pun meningkat dari 7,6 juta orang pada tahun 2008 menjadi 8,2 juta pada tahun 2012. Angka kematian akibat kanker ini menempati peringkat ketiga setelah kematian akibat penyakit kardiovaskuler (WHO, 2003). Insiden kanker diperkirakan dapat mencapai 26 juta orang pada tahun 2030 dan 17 juta di antaranya meninggal akibat kanker.

Kanker payudara merupakan jenis kanker yang paling banyak dialami oleh perempuan. Menurut Kementerian Kesehatan (Kemenkes) tahun 2014, jenis kanker terbanyak di Indonesia menurut jenis kelamin yaitu kanker payudara dan kanker leher rahimpada perempuan, sedangkan pada laki-laki yaitu kanker paru dan kanker kolorektal. Tahun 2010, jumlah pasien rawat jalan dan rawat inap pada kanker payudara yaitu 12.014 orang $(28,7 \%)$ dan kanker serviks 5.349 orang (12,8\%) (Depkes, 2010). Data rekam medis RSUPNCM tahun 2013 menunjukkan bahwa jumlah kasus kanker payudara yaitu sebanyak 2092 dan pada tahun 2014 sebanyak 1815 kasus.

Kanker payudara adalah tumor ganas yang menyerang jaringan payudara. Ciri-ciri dari kanker payudara yaitu adanya rasa sakit pada payudara, benjolan pada payudara semakin membesar, kulit payudara meneriput seperti kulit jeruk, dan terkadang keluar cairan atau darah dari puting susu (Romito et al, 2012). Selain itu, kanker payudara merupakan jenis payudara yang sering menimbulkan luka daripada jenis kanker lainnya (Lund-Nielsen, 2011). Biasanya, luka kanker akan muncul pada stadium lanjut yang membuat penderita tidak nyaman sehingga mempertimbangkan untuk mencari pertolongan kesehatan. Kondisi ini akan berdampak pada aspek psikologis penderita, yaitu perubahan citra tubuh, konsep diri, hubungan sosial, dan lainnya (Costa-Requena, Rodríguez, \& Fernández-Ortega, 2013; Romito, et al, 2012; Sarafino \& Smith, 2012).

Costa-Requena, et al. (2013) menjelaskan bahwa dampak psikososial yang dialami oleh penderita kanker payudara yaitu distres yang akan memengaruhi kualitas hidup mereka. Hinnen, et al.
(2007) menambahkan bahwa penderita akan mengalami ansietas terutama terhadap respon pasangannya karena penderita merasa sudah tidak menarik lagi dan tidak diinginkan. Ansietas dan depresi seringkali dirasakan ketika berada pada tahap lanjut, menjalani pengobatan, menunggu hasil uji diagnostik, dan sebagainya, sedangkan pemicu stres biasanya berasal dari hilangnya kemandirian dan kontrol diri, keputusasaan, ketidakberdayaan, perubahan citra diri dan fungsi tubuh, menjelang kematian (CostaRequena, et al., 2013; Murtiwi, Nurachmah, \& Nuraini, 2005; Lund-Nielsen, 2011).

Kondisi psikososial yang dialami oleh penderita kanker payudara ini merupakan kontribusi beberapa faktor, diantaranya kemampuan koping, dukungan sosial dan finansial, serta interaksi dengan orang lain. Faktor lainnya adalah jenis kanker, durasi kanker, usia, dan terapi yang dijalani (Jin-Hee, et al., 2015; Kantor, 2013). Faktor tersebut perlu diuji untuk membuktikan hubungannya sebelum diujicoba lebih lanjut mengenai intervensi keperawatan yang sesuai. Studi pendahuluan ini bertujuan untuk mengidentifikasi hubungan antara karakteristik individu, karakteristi kanker payudara dan aspek psikologis penderita.

\section{Metode}

Penelitian potong lintang ini melibatkan sebanyak 44 orang responden yang memenuhi kriteria. Pengambilan sampel dilakukan secara consecutive. Responden merupakan penderita kanker payudara yang sudah menjalani operasi pengangkatan kanker payudara dan berusia 3362 tahun. Pengumpulan data dilakukan menggunakan kuesioner Depression, Anxiety, and Stress Scale (DASS) versi Bahasa Indonesia. Uji statistik yang digunakan yaitu Chi Square, One Way Anova, dan T-independent Test.

Penelitian ini telah mendapatkan persetujuan etik dari komite etik dan perijinan adminstrasi. Selama pengambilan data dan publikasi, prinsip etika penelitian telah diterapkan. 


\section{Hasil}

Penelitian ini dilakukan pada penderita kanker payudara yang sudah menjalani operasi. Ratarata usia penderita yaitu 47 tahun, usia paling muda yaitu 33 tahun dan usia yang paling tua 62 tahun. Rerata durasi kanker yaitu 18 bulan, minimal sebulan dan yang paling lama 84 bulan.

Pada Tabel 1 dijelaskan bahwa mayoritas responden memiliki riwayat pendidikan yang tinggi, yaitu Sekolah Menengah Atas (36,4\%). Ditinjau dari pekerjaannya, sebanyak $86,4 \%$ responden tidak bekerja, sisanya bekerja sebagai wirausaha, pengajar, dan karyawan. Selain itu, dilihat dari segi penghasilan dapat dilihat bahwa lebih dari setengah responden memiliki penghasilan keluarga lebih dari $\mathrm{Rp}$ $2.700 .000(52,3 \%)$.

Berdasarkan Tabel 2 terlihat bahwa sebagian besar responden $(61,4 \%)$ melakukan terapi kombinasi, yaitu kemoterapi dan/atau sinar. Dilihat dari stadium kankernya, responden yang berada di stadium awal dan lanjut sama jumlahnya. Persentase terbanyak yaitu stadium 2 dan 3 (masing-masing 43,2\%). Selain itu, sebanyak 41 dari 44 responden, hampir semua tidak memiliki luka kanker $(93,2 \%)$.

Tabel 1. Distribusi Responden menurut Pendidikan, Pekerjaan, dan Penghasilan

\begin{tabular}{lcc}
\hline \multicolumn{1}{c}{ Karakteristik } & (n) & \% \\
\hline Pendidikan & 2 & 4,5 \\
a. Tidak Sekolah & 2 & 18,2 \\
b. SD & 7 & 15,9 \\
c. SMP & 16 & 36,4 \\
d. SMA & 11 & 25 \\
e. PT & & \\
Pekerjaan & 38 & 86,4 \\
a. Tidak bekerja & 2 & 4,5 \\
b. Wirausaha & 3 & 6,8 \\
c. Pengajar & 1 & 2,3 \\
d. Karyawan & & \\
Penghasilan & 21 & 47,7 \\
a. <Rp2.700.000 & 23 & 52,3 \\
b. $\geq$ Rp2.700.000 & 23 &
\end{tabular}

Tabel 2. Distribusi Responden menurut Terapi, Stadium, dan Luka Kanker

\begin{tabular}{|c|c|c|}
\hline Karakteristik & $\mathbf{n}$ & $\%$ \\
\hline $\begin{array}{l}\text { Terapi } \\
\text { a. Tunggal } \\
\text { b. Kombinasi }\end{array}$ & $\begin{array}{l}17 \\
27\end{array}$ & $\begin{array}{l}38,6 \\
61,4\end{array}$ \\
\hline $\begin{array}{l}\text { Stadium } \\
\text { a. Stadium } 1 \\
\text { b. Stadium } 2 \\
\text { c. Stadium } 3 \\
\text { d. Stadium } 4\end{array}$ & $\begin{array}{c}3 \\
19 \\
19 \\
3\end{array}$ & $\begin{array}{c}6,8 \\
43,2 \\
43,2 \\
6,8\end{array}$ \\
\hline $\begin{array}{l}\text { Luka kanker } \\
\text { a. Ada } \\
\text { b. Tidak }\end{array}$ & $\begin{array}{c}41 \\
3\end{array}$ & $\begin{array}{c}93,2 \\
6,8\end{array}$ \\
\hline
\end{tabular}


Tabel 3. Distribusi Responden menurut Depresi, Ansietas, dan Stres

\begin{tabular}{|c|c|c|}
\hline Karakteristik & $\mathbf{n}$ & $\%$ \\
\hline \multicolumn{3}{|l|}{ Depresi } \\
\hline a. Ringan & 42 & 95,5 \\
\hline b. Sedang & 2 & 4,5 \\
\hline \multicolumn{3}{|l|}{ Ansietas } \\
\hline a. Ringan & 35 & 79,5 \\
\hline b. Sedang & 5 & 19,4 \\
\hline c. Berat & 4 & 9,1 \\
\hline \multicolumn{3}{|l|}{ Stres } \\
\hline a. Ringan & 42 & 95,5 \\
\hline b. Sedang & 2 & 4,5 \\
\hline
\end{tabular}

Tabel 4. Hubungan Usia dan Durasi Kanker dengan Aspek Psikososial

\begin{tabular}{|c|c|c|c|c|}
\hline Variabel & Rerata & SD & p & $\mathbf{N}$ \\
\hline \multicolumn{5}{|l|}{ USIA } \\
\hline Depresi & & & 0,261 & \\
\hline a. ringan & 47,38 & 8,401 & & 42 \\
\hline b. sedang & 40,50 & 4,950 & & 2 \\
\hline Ansietas & & & 0,850 & \\
\hline a. ringan & 47,14 & 8,922 & & 35 \\
\hline b. sedang & 48,20 & 5,215 & & 5 \\
\hline c. berat & 45,00 & 7,528 & & 4 \\
\hline Stres & & & 0,225 & \\
\hline a. ringan & 47,40 & 8,370 & & 42 \\
\hline b. sedang & 40,00 & 5,657 & & 2 \\
\hline \multicolumn{5}{|l|}{ DURASI } \\
\hline Depresi & & & 0,682 & \\
\hline a. ringan & 23,36 & 38,525 & & 42 \\
\hline b. sedang & 12,00 & 4,243 & & 2 \\
\hline Ansietas & & & 0,699 & \\
\hline a. ringan & 25,17 & 41,596 & & 35 \\
\hline b. sedang & 10,40 & 9,072 & & 5 \\
\hline c. berat & 18,00 & 17,340 & & 4 \\
\hline Stres & & & 0,900 & \\
\hline a. ringan & 23,00 & 38,589 & & 42 \\
\hline b. sedang & 19.50 & 6,364 & & 2 \\
\hline
\end{tabular}

* bermakna jika $\leq \alpha=0,05$

Pada Tabel 3 memperlihatkan bahwa masalah psikososial yang paling banyak dialami oleh responden berdasarkan tingkat keparahannya yaitu ansietas. Di samping itu, tingkat keparahan depresi dan stres terlihat sama. Depresi ringan dialami hampir semua responden $(95,5 \%)$. Untuk kategori ansietas, sebagian besar responden mengalami ansietas ringan $(79,6 \%)$ dan sebagian lainnya ansietas sedang-berat $(20,4 \%)$.

Tabel 4 menjelaskan bahwa tidak ada hubungan yang signifikan antara usia dengan depresi, ansietas, stres ( $p>0,05)$. Tidak ada hubungan yang signifikan antara durasi kanker dengan depresi, ansietas, stres ( $p>0,05)$. 
Tabel 5. Hubungan Karakteristik Responden dan Kanker Payudara dengan Depresi

\begin{tabular}{|c|c|c|c|c|c|c|c|}
\hline \multirow{3}{*}{ Variabel } & \multicolumn{4}{|c|}{ Depresi } & \multirow{2}{*}{\multicolumn{2}{|c|}{ Total }} & \multirow{3}{*}{$\mathrm{p}$} \\
\hline & \multicolumn{2}{|c|}{ Ringan } & \multicolumn{2}{|c|}{ Sedang } & & & \\
\hline & $\mathrm{n}$ & $\%$ & $\mathrm{~N}$ & $\%$ & $\mathrm{n}$ & $\%$ & \\
\hline $\begin{array}{l}\text { Pendidikan } \\
\text { a. Rendah } \\
\text { b. Tinggi }\end{array}$ & $\begin{array}{l}18 \\
24\end{array}$ & $\begin{array}{l}40,9 \\
54,4\end{array}$ & $\begin{array}{l}0 \\
2\end{array}$ & $\begin{array}{c}0 \\
45\end{array}$ & 18 & $\begin{array}{l}40,9 \\
501\end{array}$ & 0,505 \\
\hline $\begin{array}{l}\text { Pekerjaan } \\
\text { a. Tidak bekerja } \\
\text { b. Bekerja }\end{array}$ & $\begin{array}{c}37 \\
5\end{array}$ & $\begin{array}{l}84,1 \\
11,4\end{array}$ & $\begin{array}{l}1 \\
1\end{array}$ & $\begin{array}{l}2,3 \\
2,3\end{array}$ & $\begin{array}{c}38 \\
6\end{array}$ & $\begin{array}{l}86,4 \\
13,6\end{array}$ & 0,257 \\
\hline $\begin{array}{l}\text { Penghasilan } \\
\text { a. Rendah } \\
\text { b. Tinggi }\end{array}$ & $\begin{array}{l}21 \\
21\end{array}$ & $\begin{array}{l}47,7 \\
47,7\end{array}$ & $\begin{array}{l}0 \\
2\end{array}$ & $\begin{array}{c}0 \\
4,5\end{array}$ & $\begin{array}{l}21 \\
23\end{array}$ & $\begin{array}{l}47,7 \\
52,3\end{array}$ & 0,489 \\
\hline $\begin{array}{l}\text { Terapi } \\
\text { a. Tunggal } \\
\text { b. Kombinasi }\end{array}$ & $\begin{array}{l}16 \\
26\end{array}$ & $\begin{array}{l}36,4 \\
59,1\end{array}$ & $\begin{array}{l}1 \\
1\end{array}$ & $\begin{array}{l}2,3 \\
2,3\end{array}$ & $\begin{array}{l}17 \\
27\end{array}$ & $\begin{array}{l}38,6 \\
61,4\end{array}$ & 1,000 \\
\hline $\begin{array}{l}\text { Stadium } \\
\text { a. Awal } \\
\text { b. Lanjut }\end{array}$ & $\begin{array}{l}21 \\
21\end{array}$ & $\begin{array}{l}47,7 \\
47,7\end{array}$ & $\begin{array}{l}1 \\
1\end{array}$ & $\begin{array}{l}2,3 \\
2,3\end{array}$ & $\begin{array}{l}22 \\
22\end{array}$ & $\begin{array}{l}50 \\
50\end{array}$ & 1,000 \\
\hline $\begin{array}{l}\text { Luka } \\
\text { a. Tidak ada } \\
\text { b. Ada }\end{array}$ & $\begin{array}{c}40 \\
2\end{array}$ & $\begin{array}{c}90,9 \\
4,5\end{array}$ & $\begin{array}{l}1 \\
1\end{array}$ & $\begin{array}{l}2,3 \\
2,3\end{array}$ & $\begin{array}{c}41 \\
3\end{array}$ & $\begin{array}{c}93,2 \\
6,8\end{array}$ & 0,133 \\
\hline
\end{tabular}

*Ket: nilai p bermakna jika $\leq \alpha 0,05$

Tabel 6. Hubungan Karakteristik Responden dan Kanker Payudara dengan Ansietas

\begin{tabular}{|c|c|c|c|c|c|c|c|c|c|}
\hline \multirow{3}{*}{ Variabel } & \multicolumn{6}{|c|}{ Ansietas } & \multirow{2}{*}{\multicolumn{2}{|c|}{ Total }} & \multirow{3}{*}{$\mathrm{p}$} \\
\hline & \multicolumn{2}{|c|}{ Ringan } & \multicolumn{2}{|c|}{ Sedang } & \multicolumn{2}{|c|}{ Berat } & & & \\
\hline & $\mathrm{n}$ & $\%$ & $\mathrm{n}$ & $\%$ & $\mathrm{n}$ & $\%$ & $\mathrm{n}$ & $\%$ & \\
\hline $\begin{array}{l}\text { Pendidikan } \\
\text { a. Rendah } \\
\text { b. Tinggi }\end{array}$ & $\begin{array}{l}11 \\
24\end{array}$ & $\begin{array}{c}25 \\
54,5\end{array}$ & $\begin{array}{l}4 \\
1\end{array}$ & $\begin{array}{l}9,1 \\
2,3\end{array}$ & $\begin{array}{l}3 \\
1\end{array}$ & $\begin{array}{l}6,8 \\
2,3\end{array}$ & $\begin{array}{l}18 \\
26\end{array}$ & $\begin{array}{l}40,9 \\
59,1\end{array}$ & $0,041^{*}$ \\
\hline $\begin{array}{l}\text { Pekerjaan } \\
\text { a. Tidak bekerja } \\
\text { b. Bekerja }\end{array}$ & $\begin{array}{c}30 \\
5\end{array}$ & $\begin{array}{l}68,2 \\
11,4\end{array}$ & $\begin{array}{l}4 \\
1\end{array}$ & $\begin{array}{l}9,1 \\
2,3\end{array}$ & $\begin{array}{l}4 \\
0\end{array}$ & $\begin{array}{c}9,1 \\
0\end{array}$ & $\begin{array}{c}38 \\
6\end{array}$ & $\begin{array}{l}86,4 \\
13,6\end{array}$ & 0,665 \\
\hline $\begin{array}{l}\text { Penghasilan } \\
\text { a. Rendah } \\
\text { b. Tinggi }\end{array}$ & $\begin{array}{l}17 \\
18\end{array}$ & $\begin{array}{l}38,6 \\
40,9\end{array}$ & $\begin{array}{l}3 \\
2\end{array}$ & $\begin{array}{l}6,8 \\
4,5\end{array}$ & $\begin{array}{l}1 \\
2\end{array}$ & $\begin{array}{l}2,3 \\
6,8\end{array}$ & $\begin{array}{l}21 \\
23\end{array}$ & $\begin{array}{l}47,7 \\
52,3\end{array}$ & 0,566 \\
\hline $\begin{array}{l}\text { Terapi } \\
\text { a. Tunggal } \\
\text { b. Kombinasi }\end{array}$ & $\begin{array}{l}14 \\
21\end{array}$ & $\begin{array}{l}31,8 \\
47,7\end{array}$ & $\begin{array}{l}3 \\
2\end{array}$ & $\begin{array}{l}6,8 \\
4,5\end{array}$ & $\begin{array}{l}0 \\
4\end{array}$ & $\begin{array}{c}0 \\
9,1\end{array}$ & $\begin{array}{l}17 \\
27\end{array}$ & $\begin{array}{l}38,6 \\
61,4\end{array}$ & 0,173 \\
\hline $\begin{array}{l}\text { Stadium } \\
\text { a. Awal } \\
\text { b. Lanjut }\end{array}$ & $\begin{array}{l}18 \\
17\end{array}$ & $\begin{array}{l}40,9 \\
38,6\end{array}$ & $\begin{array}{l}3 \\
2\end{array}$ & $\begin{array}{l}6,8 \\
4,5\end{array}$ & $\begin{array}{l}1 \\
3\end{array}$ & $\begin{array}{l}2,3 \\
6,8\end{array}$ & $\begin{array}{l}22 \\
22\end{array}$ & $\begin{array}{l}50 \\
50\end{array}$ & 0,541 \\
\hline $\begin{array}{l}\text { Luka } \\
\text { a. Tidak ada } \\
\text { b. Ada }\end{array}$ & $\begin{array}{c}33 \\
2\end{array}$ & $\begin{array}{c}75 \\
4,5\end{array}$ & $\begin{array}{l}4 \\
1\end{array}$ & $\begin{array}{l}9,1 \\
2,3\end{array}$ & $\begin{array}{l}4 \\
0\end{array}$ & $\begin{array}{c}9,1 \\
0\end{array}$ & $\begin{array}{c}41 \\
3\end{array}$ & $\begin{array}{c}93,2 \\
6,8\end{array}$ & 0,422 \\
\hline
\end{tabular}

*Ket: nilai $\mathrm{p}$ bermakna jika $\leq \alpha 0,05$ 
Tabel 7. Hubungan Karakteristik Responden dan Kanker Payudara dengan Stres

\begin{tabular}{|c|c|c|c|c|c|c|c|}
\hline \multirow{3}{*}{ Variabel } & \multicolumn{4}{|c|}{ Stres } & \multirow{2}{*}{\multicolumn{2}{|c|}{ Total }} & \multirow{3}{*}{$\mathrm{p}$} \\
\hline & \multicolumn{2}{|c|}{ Ringan } & \multicolumn{2}{|c|}{ Sedang } & & & \\
\hline & $\mathrm{n}$ & $\%$ & $\mathrm{~N}$ & $\%$ & $\mathrm{n}$ & $\%$ & \\
\hline $\begin{array}{l}\text { Pendidikan } \\
\text { a. Rendah } \\
\text { b. Tinggi }\end{array}$ & $\begin{array}{l}17 \\
25\end{array}$ & $\begin{array}{l}38,6 \\
56,8\end{array}$ & $\begin{array}{l}1 \\
1\end{array}$ & $\begin{array}{l}2,3 \\
2,3\end{array}$ & $\begin{array}{l}18 \\
26\end{array}$ & $\begin{array}{l}40,9 \\
59,1\end{array}$ & 1,000 \\
\hline $\begin{array}{l}\text { Pekerjaan } \\
\text { a. Tidak bekerja } \\
\text { b. Bekerja }\end{array}$ & $\begin{array}{c}37 \\
5\end{array}$ & $\begin{array}{l}84,1 \\
11,4\end{array}$ & $\begin{array}{l}1 \\
1\end{array}$ & $\begin{array}{l}2,3 \\
2,3\end{array}$ & $\begin{array}{c}38 \\
6\end{array}$ & $\begin{array}{l}86,4 \\
13,6\end{array}$ & 0,257 \\
\hline $\begin{array}{l}\text { Penghasilan } \\
\text { a. Rendah } \\
\text { b. Tinggi }\end{array}$ & $\begin{array}{l}20 \\
22\end{array}$ & $\begin{array}{c}45,5 \\
50\end{array}$ & $\begin{array}{l}1 \\
1\end{array}$ & $\begin{array}{l}2,3 \\
2,3\end{array}$ & $\begin{array}{l}21 \\
23\end{array}$ & $\begin{array}{l}47,7 \\
52,3\end{array}$ & 1,000 \\
\hline $\begin{array}{l}\text { Terapi } \\
\text { a. Tunggal } \\
\text { b. Kombinasi }\end{array}$ & $\begin{array}{l}16 \\
26\end{array}$ & $\begin{array}{l}36,4 \\
59,1\end{array}$ & $\begin{array}{l}1 \\
1\end{array}$ & $\begin{array}{l}2,3 \\
2,3\end{array}$ & $\begin{array}{l}17 \\
27\end{array}$ & $\begin{array}{l}38,6 \\
61,4\end{array}$ & 1,000 \\
\hline $\begin{array}{l}\text { Stadium } \\
\text { a. Awal } \\
\text { b. Lanjut }\end{array}$ & $\begin{array}{l}22 \\
20\end{array}$ & $\begin{array}{c}50 \\
45,5\end{array}$ & $\begin{array}{l}0 \\
2\end{array}$ & $\begin{array}{c}0 \\
4,5\end{array}$ & $\begin{array}{l}22 \\
22\end{array}$ & $\begin{array}{l}50 \\
50\end{array}$ & 0,488 \\
\hline $\begin{array}{l}\text { Luka } \\
\text { a. Tidak ada } \\
\text { b. Ada }\end{array}$ & $\begin{array}{c}40 \\
2\end{array}$ & $\begin{array}{c}90,9 \\
4,5\end{array}$ & $\begin{array}{l}1 \\
1\end{array}$ & $\begin{array}{l}2,3 \\
2,3\end{array}$ & $\begin{array}{c}41 \\
3\end{array}$ & $\begin{array}{c}93,2 \\
6,8\end{array}$ & 0,133 \\
\hline
\end{tabular}

* bermakna jika $\leq \alpha 0,05$

Uji analisis yang telah dilakukan menunjukkan bahwa pendidikan, pekerjaan, penghasilan, terapi, stadium, dan keberadaan luka tidak memiliki hubungan dengan depresi $(\mathrm{p}>0,05)$ (lihat Tabel 5).

Uji analisis yang telah dilakukan menunjukkan bahwa pekerjaan, penghasilan, terapi, stadium, dan keberadaan luka tidak memiliki hubungan dengan ansietas pada alpha 5\% (lihat Tabel 6). Hanya pendidikan yang berhubungan dengan ansietas $(\mathrm{p}<0,05)$.

Uji analisis yang telah dilakukan menunjukkan bahwa pendidikan, pekerjaan, penghasilan, terapi, stadium, dan keberadaan luka tidak memiliki hubungan dengan stres $(p>0,05)$ (lihat Tabel 7). Hasil uji statistik pada variabel pekerjaan, penghasilan, terapi dan stadium diperoleh nilai $\mathrm{p}=1,000$, sedangkan untuk variabel pekerjaan nilai $\mathrm{p}=0,257$, terapi 0,488 , dan luka 0,133 .

\section{Pembahasan}

Hasil penelitian menggambarkan rerata usia responden yaitu 47 tahun. Kanker payudara lebih berisiko dialami pada wanita berusia lebih dari 35 tahun, sedangkan wanita yang berusia kurang dari 30 tahun tidak memiliki risiko yang besar (Kumar, Koul, Khandrika, Meacham, \& Koul, 2008). Hal ini dikarenakan pada usia 3550 tahun mulai terjadi ketidakseimbangan pada kadar hormon estrogen dan progesteron dalam tubuh sehingga mengaktifkan pertumbuhan sel kanker (Jokiel, 2009). Hasil penelitian ini menunjukkan bahwa tidak ada hubungan antara usia dengan depresi, ansietas, dan stres. Hal ini sejalan dengan penelitian Kim et al. (2012) tentang faktor depresi pada penderita kanker payudara di Korea yang telah melakukan operasi pengangkatan payudara. Pada penelitian tersebut ditemukan bahwa tidak ada hubungan antara usia dengan depresi $(\mathrm{p}=0,516)$. Dengan usia rerata 47 tahun, sebagian besar penderita 
merasa masih memiliki tanggung jawab yang besar seperti mengurus keluarga dan anak sehingga harapan hidup dan motivasi diri untuk sembuh masih kuat. Kondisi ini memaksa para penderita untuk lebih banyak berpikir positif.

Tidak adanya hubungan antara pendidikan dengan depresi maupun stres dapat terjadi karena tidak semua penderita yang berpendidikan rendah memiliki pengetahuan yang rendah pula. Hal ini didukung oleh ulasan Wulandari (2013) yang menyatakan bahwa pasien kanker payudara yang berpendidikan rendah lebih antusias dalam mencari informasi tentang penyakit yang dideritanya serta pengobatan yang dapat dilakukan untuk menyembuhkan penyakitnya.

Pada penelitian ini, tidak terdapat hubungan antara pendidikan dengan depresi dan stres, namun ditemukan adanya hubungan antara pendidikan dengan ansietas (nilai $\mathrm{p}=0,041$ ). Penelitian Dewi, Djoenaina, dan Melisa (2004) juga menunjukkan tidak ada hubungan antara pendidikan dengan depresi $(p>0,05)$. Hasil ini bertentangan dengan kenyataan bahwa tingkat pendidikan dapat memengaruhi tingkat pengetahuan seseorang dalam memperoleh informasi tentang penyakit (Prasetya, Hamid, \& Susanti, 2010; \& White, Riley, \& Smith, 2008). Kecukupan informasi akan membentuk perasaan, sikap, perilaku, pembuatan keputusan yang baik sehingga mencegah penderita untuk merasakan depresi, ansietas, maupun stres.

Penelitian ini menunjukkan bahwa tidak ada hubungan antara pekerjaan dengan depresi, ansietas, maupun stres. Hasil ini mendukung penelitian oleh Anindita et al. (2010) yang juga menunjukkan tidak adanya hubungan antara penghasilan dengan depresi, ansietas, dan stres dengan nilai p masing-masing 0,609, 0,709, dan 0,446 . Status pekerjaan saat ini dapat dikaitkan dengan penghasilan atau pendapatan yang berpengaruh pada biaya pengobatan. Selain itu, pekerjaan berkaitan dengan aktivitas dan istirahat yang mungkin memengaruhi tingkat stres seseorang. Depresi paling banyak terjadi pada penderita yang tidak bekerja karena penderita yang tidak bekerja memiliki aktivitas lebih sedikit, sedangkan aktivitas fisik dapat mengurangi beban psikologis seseorang (Wulandari, 2013).

Tidak ditemukan hubungan antara penghasilan dengan depresi, ansietas, maupun stres pada hasil penelitian. Hal ini juga didukung dengan penelitian oleh Karvinen et al. (2013) tentang stres, perilaku kesehatan, dan pemenuhan layanan medis pada pasien kanker payudara. Pada penelitian tersebut tidak ditemukan adanya hubungan antara penghasilan dengan ansietas (nilai $\mathrm{p}>0,05$ ). Penghasilan atau pendapatan dapat dikaitkan dengan biaya pengobatan yang harus dikeluarkan. Pengobatan kanker dalam jangka waktu yang lama dan terus menerus memakan biaya yang tidak murah walaupun saat ini pun sudah banyak orang yang menggunakan jaminan kesehatan nasional.

Pada penelitian ini, tidak terdapat hubungan antara durasi kanker dengan depresi, ansietas, maupun stres. Pada penelitian Kim et al. (2012) ditunjukkan bahwa tidak ada hubungan antara durasi kanker dengan depresi (nilai $\mathrm{p}=0,650$ ). Penderita kanker yang baru didiagnosa akan sulit menerima penyakitnya dan timbul berbagai penolakan. Menurut teori eksistensial, depresi terjadi karena adanya perbedaan yang terlalu besar antara ideal diri dan kenyataan. Rata-rata durasi kanker pada penelitian ini yaitu 18 bulan. Penderita yang sudah lebih dari satu tahun menjalani terapi sejak didiagnosa akan lebih tenang daripada yang baru didiagnosa.

Selain itu, menurut Hoefler, et al. (2015), penderita membutuhkan waktu tertentu untuk melakukan mekanisme pertahanan dalam melawan atau menahan perasaan cemas, takut, atau stres. Mekanisme pertahanan yang baik merupakan pertahanan yang berasal dari dalam diri, namun dukungan dari luar juga diperlukan agar keadaan psikologisnya menjadi seimbang (Wulandari, 2013).

Tidak ditemukan hubungan antara terapi dengan depresi, ansietas, maupun stres. Hal ini 
sejalan dengan penelitian Kim, et al. tahun 2012. Pada penelitian tersebut ditemukan bahwa tidak ada hubungan antara terapi dengan depresi $(\mathrm{p}=0,279)$. Jenis terapi yang didapatkan dapat memengaruhi aspek psikososial penderita kanker payudara. Penderita yang menjalani operasi pengangkatan kanker payudara saja dapat memiliki gangguan citra tubuh, harga diri rendah, dan perubahan fungsi seksual. Di sisi lain, biasanya penderita merasa lebih tenang dan tidak perlu khawatir terhadap kekambuhan kanker karena kanker sudah diangkat. Berbeda dengan operasi saja, jika terapi ditambah terapi lainnya seperti kemoterapi atau radioterapi, penderita merasa stres dengan efek samping yang ditimbulkan.

Dukungan sosial juga memengaruhi penderita dalam menjalani terapi. Dukungan sosial merupakan bentuk bantuan yang dirasakan seseorang yang dapat menumbuhkan perasaan nyaman, percaya diri, semangat, serta meningkatkan kesehatan mental seseorang yang diperoleh melalui hubungan interpersonal. Sumber dukungan sosial yang terbesar datangnya dari orang yang misalnya keluarga, pasangan, sahabat, dan rekan kerja. Dukungan dapat menurunkan tingkat kecemasan, gangguan umum, somatisasi, dan depresi. Bentuk dukungan itu sendiri dapat berupa dukungan emosional, dukungan penghargaan, dukungan instrumental, dukungan informasi dan dukungan jaringan sosial (Sarafino \& Smith, 2012).

Pada penelitian ini, tidak terdapat hubungan antara stadium dengan depresi, ansietas, maupun stres. Penelitian oleh Dewi, et al. (2004) juga menunjukkan bahwa tidak ada hubungan antara durasi dengan depresi (nilai p>0,05). Reaksi psikologis penderita kanker yang berada pada stadium awal dan lanjut bisa berbeda. Pada stadium lanjut, kanker dapat menyebar ke organ tubuh lain sehingga dapat memperparah penyakit. Dengan begitu, terapi yang dijalankannya pun menjadi lebih kompleks. Akibat dari keparahan penyakitlah yang menyebabkan masalah psikososial.
Untuk mengatasinya, diperlukan manajemen koping yang adaptif. Manajemen koping merupakan faktor psikologis yang dapat mengurangi atau menahan stres. Penderita pasti merasa sangat sulit untuk menerima dirinya karena penyakit dan pengobatan kanker ini menimbulkan stres secara terus menerus. Penderita dengan stadium lanjut dapat mengalami gangguan psikologis dan penolakan diri berat sehingga dapat memperburuk keadaan penderita (Wulandari, 2013).

Tidak ditemukan adanya hubungan antara keberadaan luka kanker dengan depresi, ansietas, dan stres pada hasil penelitian. Luka kanker yang muncul akibat pecahnya pembuluh darah di jaringan payudara akibat keganasan sel kanker akan mengeluarkan cairan dan bau yang tidak sedap. Selain itu, timbul nyeri yang sangat sehingga penderita merasa terganggu dalam menjalankan aktivitas. Bau tidak sedap yang ditimbulkan juga membuat penderita cemas jika orang di sekitarnya akan menjauh dari dirinya. Penderita dapat merasa rendah diri, megurung diri, dan tidak ingin berinteraksi dengan siapapun.

Pada penelitian ini, hampir semua responden tidak memiliki luka. Hal ini dikarenakan penelitian dilakukan pada perempuan yang sudah menjalankan operasi pengangkatan kanker payudara sehingga luka kanker sudah diangkat bersama jaringan payudara. Keterbatasan lainya berkaitan dengan besar sampel dan tidak diidentifikasinya faktor lain yang kemungkinan berhubungan dengan aspek psikologis pada penderita kanker payudara.

\section{Kesimpulan}

Penderita kanker payudara sangat rentan memiliki masalah psikososial sehingga kualitas hidup dapat terpengaruh. Hasil Studi pendahuluan ini menunjukkan tidak ada hubungan antara usia, pendidikan, pekerjaan, penghasilan, durasi, terapi, stadium, dan luka kanker dengan depresi, ansietas, dan stres, namun ditemukan 
adanya hubungan antara pendidikan dengan ansietas. Hal ini menggambarkan penderita yang sudah menjalani operasi dan memiliki kanker selama kurang lebih 1,5 tahun sudah dapat beradaptasi dan menggunakan kemampuan kopingnya dengan baik walaupun masih ada yang memiliki masalah psikososial yang ringan. Hasil studi ini dapat menjadi dasar penelitian lanjut mengenai faktor yang memengaruhi aspek psikososial pada penderita kanker yang memiliki luka, dan yang baru didiagnosis. Selanjutnya dapat dikembangkan [rogram pelatihan untuk mengatasi masalah psikososial pada penderita kanker payudara dalam rangka meningkatkan kesejahteraan para penyintas kanker (SR, HR, INR).

\section{Referensi}

Anindita, Y. P. C., Marchira, C. R., \& Prabandari, Y. S. (2010). Hubungan antara pemberian radioterapi dengan terjadinya distress, anxiety , dan depresi pada penderita kanker payudara. Berita Kedokteran Masyarakat, 26 (1), 1-6.

Costa-Requena, G., Rodríguez, A., \& FernándezOrtega, P. (2013). Longitudinal assessment of distress and quality of life in the early stages of breast cancer treatment. Scandinavian Journal of Caring Sciences, 27 (1), 77-83. doi:10.1111/j.1471-6712.2012.01003.x

Depkes RI. (2010). Laporan hasil riset kesehatan dasar Indonesia tahun 2010. Jakarta: Badan Penelitian dan Pengembangan Kesehatan Depkes RI.

Dewi, F.I.R., Djoenaina, V., \& Melisa. (2004). Hubungan antara resiliensi dengan depresi pada perempuan pasca pengangkatan payudara (mastektomi). Jurnal Psikologi, 2 (2).

Hinnen, C., Hagedoorn, M., Sanderman, R., \& Ranchor, A. (2007). The role of distress, neuroticism and time since diagnosis in explaining support behaviors in partners of women with breast cancer: Results of a longitudinal analysis. Psycho-Oncology, 16 (10), 913-919. DOI: 10.1002/pon.1153
Hoefler, A., Athenstaedt, U., Corcoran, K., Ebner, F., \& Ischebeck, A. (2015). Coping with selfthreat and the evaluation of self-related traits: An fMRI Study. Plos One, 10 (9), e0136027. doi: 10.1371/journal.pone. 0136027

Jin-Hee, P., Hyoung, B.S, Mison, C., Yong-Sik, J., \& Young-Mi, J. (2015). Factors influencing elevated distress scores at the end of primary treatment of breast cancer. Asian Oncology Nursing, 15 (3), 132-139. doi: 10.5388/aon. 2015.15.3.132

Jokiel, M. (2009). Social aspects of breast cancer early detection after introduction of population screenings in Poland. Przeglad Epidemiologiczny, 63 (3), 443-447.

Kantor, D.P. (2013, January). Factors influencing psychological distress in patients with cancer. Factors Influencing Psychological Distress in Patients with Cancer, 174 p.

Karvinen, K. H., Murray, N. P. Arastu, H., \& Allison, R. R. (2013). Stress reactivity, health behaviors, and compliance to medical care in breast cancer survivors. Oncology Nursing Forum, 40 (2), 149-156.

Kementerian Kesehatan RI. (2014). Profil kesehatan Indonesia tahun 2013. Jakarta: Kementerian Kesehatan RI. Diperoleh dari http://www.depkes.go.id/resources/download /pusdatin/profil-kesehatan-indonesia/profilkesehatan-indonesia-2013.pdf

Kim, S., Stewart, R., Kim., S., Yang, S.J., Kim, J.M., Shin, I.S., Park, M.H., Yoon, J.H., \& Yoon, J.S. (2012). Predictors of depression in Korean breast cancer patients: A one-year longitudinal study. Asia-Pacific Psychiatry, 4, 250-257. doi: 10.1111/j.1758-5872.2012. 00197.x

Kumar, B., Koul, S., Khandrika, L., Meacham, R.B., \& Koul, H.K. (2008). Oxidative stress is inherent in prostate cancer cells and is required for aggressive phenotype. Cancer research, 68 (6), 1777-1785. doi: 10.1158/ 0008-5472.CAN-07-5259. 
Lund-Nielsen, B. (2011). Malignant wounds in patients with advanced stage cancer. [Disertasi]. University of Copenhagen.

Manne, S.L., \& Ostroff, J.S. (2008). Coping with breast cancer. Oxford: Oxford University Press.

Murtiwi, M., Nurachmah, E., \& Nuraini, T. (2005). Kualitas hidup klien kanker yang menerima pelayanan hospis atau homecare: Suatu analisis kuantitatif. Jurnal Keperawatan Indonesia, 9 (1), 13-18. http://dx.doi.org/10. 7454/ jki.v9i1.154

Prasetya, A., Hamid, A., \& Susanti, H. (2010). Penurunan tingkat depresi klien lansia dengan terapi kognitif dan senam latihan otak di Panti Wredha. Jurnal Keperawatan Indonesia, 13 (1), 42-48. http://dx.doi.org/10.7454/jki.v13 i1.230

Remennick, L. (2006). The challenge of early breast cancer detection among immigrant and minority women in multicultural societies. Breast J., 12 (Suppl 1), S103-S110.

Romito, F., Cormio, C., Giotta, F., Colucci, G., \& Mattioli, V. (2012) Quality of life, fatigue and depression in Italian long-term breast cancer survivors. Support Care Cancer, 20, 29412948
Sarafino, E. P., \& Smith, T. W. (2012). Health psychology: Biopsychosocial interactions (7th Ed.). New York: John Wiley \& Sons, Inc.

White, C., Riley, A., \& Smith, S. (2008). Awareness of depression at the reception desk: Education for primary care receptionists. Education For Primary Care, 19 (2), 173-190.

World Health Organization. (2003). The Impact of Chronic Disease in Indonesia. Diperoleh dari http://www.who.int/chp/chronic_disease_rep ort/media/impact/indonesia.pdf

World Health Organization. (2013). Latest World Cancer Statistic. Diperoleh dari http://www. iarc.fr/en/media-centre/pr/2013/pdfs/pr223_ E.pdf

Wulandari, P. (2013). Faktor-faktor yang mempengaruhi kejadian depresi pada pasien kanker payudara di RSUPN DR Cipto Mangunkusumo Jakarta (Tesis, tidak Dipublikasi). Depok: Fakulas Ilmu Keperawatan Universitas Indonesia. 